\title{
OAK FOREST VEGETATION IN THE NORTHERN PART OF THE ŠTIAVNICKÉ VRCHY MTS (CENTRAL SLOVAKIA)
}

\author{
Michal SLEZÁK ${ }^{1} \&$ Anna PETRÁŠOVÁ
}

\begin{abstract}
The phytosociological research of the oak forest vegetation was carried out in the northern part of the Štiavnické vrchy Mts (Central Slovakia) using the standard Zürich-Montpellier approach. The data set consisting of 41 phytosociological relevés was obtained by the authors in two vegetation seasons in 2008 and 2009. The numerical classification and the ordination methods were applied to determine the main vegetation types and to explain the structure of the vegetation-environmental data matrix, respectively. Four associations within two classes were distinguished: Luzulo albidae-Quercetum petraeae Hilitzer 1932, typical for shallow, mineral-poor and acidic soils, Melico uniflorae-Quercetum petraeae Gergely 1962 occuring on mesic stands with skeletal and deeper soils, Poo nemoralis-Quercetum dalechampii Šomšák et Háberová 1979 developing on moderately canopyopened stands in the submontane belt, Sorbo torminalis-Quercetum Svoboda ex Blažková 1962 growing on moderately acidic substrates in drier regions. The major environmental gradients responsible for variation in forest species composition was associated with soil nutrient and soil reaction following the Ellenberg indicator values as well as the measured environmental variables (C/N-ratio and soil acidity). Special attention was given to the discussion on species composition and site ecology.

Key words: classification, phytosociology, ecology, Quercetea robori-petraeae, Querco-Fagetea, gradient analysis, the Western Carpathians.

\section{Izvleček}

Fitocenološke raziskave hrastovih gozdov v severnem delu gorovja Štiavnické vrchy (srednja Slovaška) smo naredili po Zürichško-Montpellierski metodi. Enainštirideset vegetacijskih popisov smo naredili v dveh vegetacijskih sezonah v letih 2008 in 2009. Za določitev glavnih vegetacijskih tipov in za obrazložitev strukture podatkovne matrike vegetacijskih popisov in ekoloških spremenljivk smo uporabili numerično klasifikacijo in ordinacijo. Znotraj dveh razredov smo ločili štiri asociacije: Luzulo albidae-Quercetum petraeae Hilitzer 1932, značilna za plitva, z minerali revna, kisla tla, Melico uniflorae-Quercetum petraeae Gergely 1962, ki se pojavlja na mezičnih rastiščih s skeletnimi, globljimi tlemi, Poo nemoralis-Quercetum dalechampii Šomšák et Háberová 1979, ki se razvije v zmerno odprtih sestojih v submontanskem pasu, Sorbo torminalis-Quercetum Svoboda ex Blažková 1962 pa uspeva na zmerno kislih tleh v sušnejših predelih. Glavna okoljska gradienta, ki vplivata na floristično sestavo, sta hranila v tleh in reakcija tal. Odražata se tako v Ellenbergovih indikatorskih vrednostih kot v merjenih okoljskih spremenljivkah (C/N razmerje in kislost tal). Poseben poudarek smo namenili diskusiji o vrstni sestavi in ekologiji rastišč.
\end{abstract}

Ključne besede: klasifikacija, fitosociologija, ekologija, Quercetea robori-petraeae, Querco-Fagetea, gradientna analiza, zahodni Karpati.

\footnotetext{
${ }^{1}$ Institute of Forest Ecology, Slovak Academy of Sciences, Štúrova 2, SK-960 01 Zvolen, Slovak Republic; e-mail: slezak.miso@gmail.com

${ }^{2}$ Faculty of Natural Sciences, Matej Bel University, Tajovského 40, SK-974 01 Banská Bystrica, Slovak Republic; e-mail: petrasov@fpv.umb.sk
} 


\section{INTRODUCTION}

The genus Quercus (Fagaceae) represents one of the most abundant groups of trees in temperate Europe (Nixon 1993). It is considered a taxonomically complicated group with high frequency of hybridization. This process has been reflected in the difficult determination of some oak species and also in different evaluation of their taxonomic status (Gömöry et al. 2001, Franjić et al. 2006). The species composition and proportion of Quercus species in the tree layer of the CarpathianPannonian forest vegetation changes depending on the site conditions mainly soil depth and soil water availability (cf. Jakucs 1961, Ellenberg 1982, Magic 2006). Among the oak species native to this area (cf. Magic l.c.), $Q$. petraea agg. (incl. $Q$. petraea s. str., $Q$. dalechampii, $Q$. polycarpa) and $Q$. cerris are the most frequently dominating taxa.

The oak forests are important elements of the natural Carpathian-Pannonian vegetation, and they are substantial habitats of many endangered species (cf. Jakucs 1961). Except for two associations included into the order Fagetalia, the oak forest vegetation types have been traditionally classified in the territory of Slovakia into the orders Quercetalia roboris and Quercetalia pubescenti-petraeae (Jarolímek et al. 2008a). Acidophilous oak forests of the order Quercetalia roboris are commonly developed on a mineral deficient substrate with shallow soil, whereas the xero- and thermophilous oak forests of the order Quercetalia pubescenti-petraeae are associated on shallow to deep soils containing a high concentration of mineral nutrients, especially in areas with a drier and warmer microclimate. Oak forest vegetation has already been several times investigated in the past. Additionally to the regional phytosociological studies from various parts of Slovakia (e.g. Klika 1937, Michalko 1957, Neuhäusl \& Neuhäuslová-Novotná 1964, Neuhäuslová-Novotná 1965, Šomšák \& Háberová 1979, Kliment \& Watzka 2000, Slezák \& Kukla 2009a), there are a few papers exclusively devoted to their floristic differentiation patterns and spatial distribution (Šomšák 1963, Jurko 1965, Neuhäuslová-Novotná \& Neuhäusl 1965, Miadok 1991, Chytrý 1994, Kanka 2001, Roleček 2004). Despite the fact that nowadays a part of thermophilous oak forests of the order Quercetalia pubescenti-petraeae has been discussed by Roleček (2005), the syntaxonomy of the oak forest vegetation types requires a comprehensive revision.
The Štiavnické vrchy Mts are volcanic mountains situated in the central part of Slovakia (Figure 1). They occupy a geographic territory in the transition zone between the Western Carpathian and the Pannonian phytogeographic region. Mountain units situated on the border of these regions belong generally to the botanicaly attractive areas. Due to the diversity of both plant species and communities, they have been recently the subject of some studies (e.g. Michálková 2007, Hrivnák et al. 2008).

A basic survey of forest communities of the study area has been partially outlined by Balkovič (2002) and Slezák \& Hegedüšová (2010), although only a little information is available on the ecological patterns of the oak forests. The data on their variability and floristic composition are relatively rare. Although some individual relevés were published in papers focusing on floristical records (e.g. Slezák \& Kukla 2009b), the detailed classification and description of site ecology remain still poorly known. For this reason, the aim of the current paper is to establish the main vegetation types of oak forests in the northern part of the Stiavnické vrchy Mts and to characterise their major environmental gradients.

\section{METHODS}

The vegetation study was carried out according to the principles of the standard Zürich-Montpellier approach using the modified 9-degree BraunBlanquet scale (Barkman et al. 1964). Forty-one phytosociological relevés with dominance or codominance (at least $25 \%$ cover in the tree layer) of an oak species were recorded by the authors in the northern part of the Štiavnické vrchy Mts in 2008-2009 and stored in a TURBOVEG database (Hennekens \& Schaminée 2001). Numerical classification of the data set was performed by the Hierclus program from the SYN-TAX 2000 package (Podani 2001) with the Sørensen (BrayCurtis) distance as a measure of dissimilarity and the beta-flexible linkage method $(\beta=-0.25)$. Species percentage cover was logarithmically transformed. The optimal number of clusters was estimated by the 'crispness' method (Botta-Dukát et al. 2005) using the JUICE software (Tichý 2002). The same woody species recorded in different layers were merged for the purpose of the numerical classification. The moss layer was also integrated in the analysis. The diagnostic species 


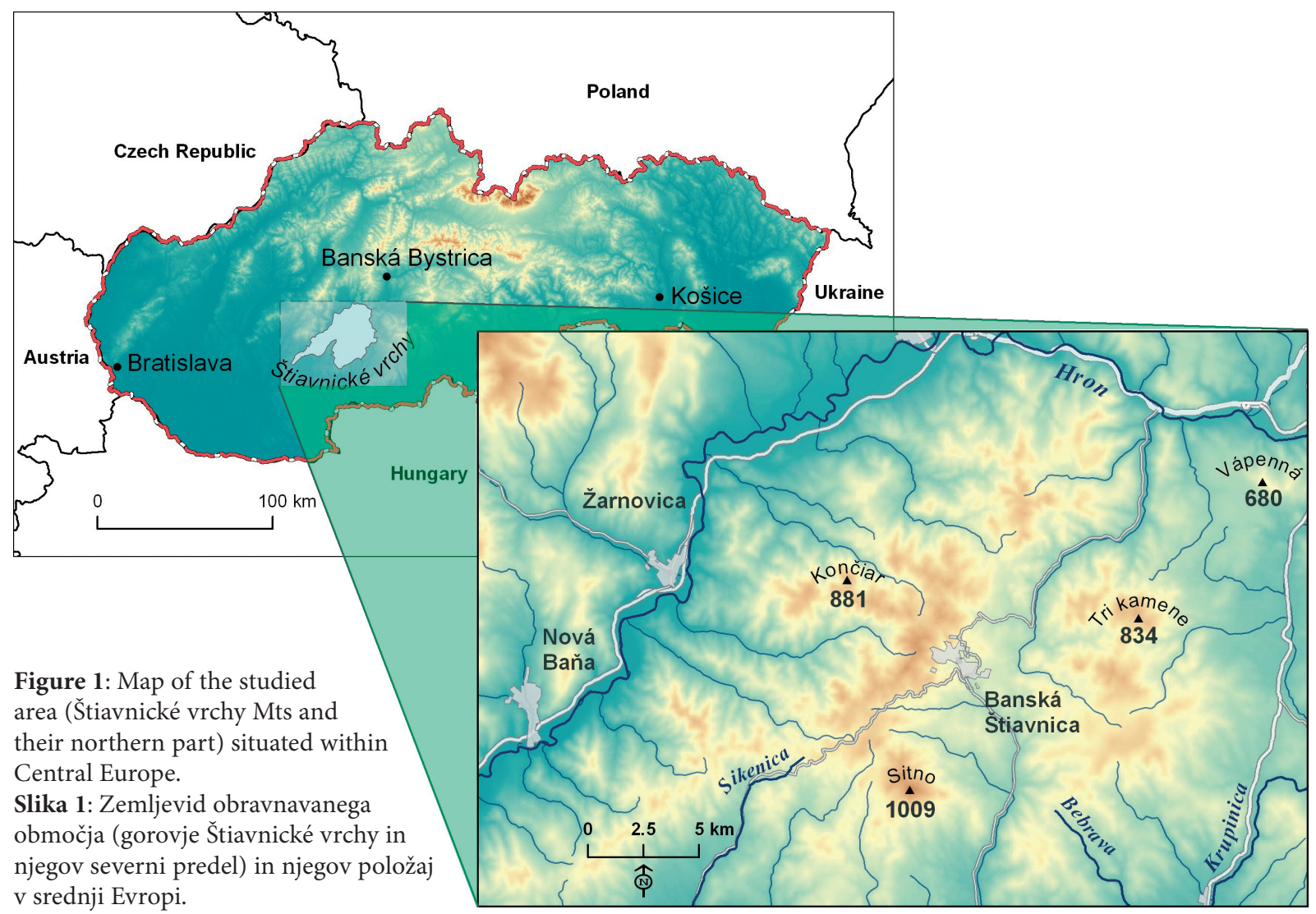

of the associations were determined on the basis of the fidelity concept (Chytrý et al. 2002) and frequency in the JUICE software. The size of all clusters was standardized to an equal size (Tichý \& Chytrý 2006). The species with simultaneous values of phi coefficient $>0.30$ and frequency > 30 were considered as diagnostic ones. Fisher's exact test $(P<0.05)$ was used to eliminate the fidelity value of species with a non-significant pattern of occurrence. The results of classification are summarised in Table 1, in which the assignment of species to higher vegetation units (alliances, classes) follows Moravec (1998), Moravec et al. (2000) and Jarolímek et al. (2008b). The percentage constancy (frequency) was given for each species in individual clusters and species were ranked by the decreasing value. Since the diagnostic species were obtained from an analysis of deciduous oak forests from a part of the Štiavnické vrchy Mts, they are only of a local validity. Detrended correspondence analysis (DCA) using the CANOCO for Windows package (ter Braak \& Šmilauer 2002) was used to explain the structure of the vegetation-environmental data matrix and to interpret the main environmental gradients. Ellenberg indicator values for vascular plants (Ellenberg et al. 1992) and measured environmental variables for vegetation plots were plotted onto a DCA ordination diagram as supplementary variables. Geographical coordinates (longitude, latitude) and altitude were measured by the Garmin GPSmap 60 CSx (WGS 84).

Understory light conditions were recorded by the hemispherical photographs. Their processing and calculation of canopy openness (CO), i.e. the percentage of open sky seen from beneath a forest canopy (Jelaska 2004), was subsequently done using Gap Light Analyser software (Frazer et al. 1999). Soil samples were randomly taken in three places in each vegetation plot from the uppermost mineral horizon $(0-5 \mathrm{~cm}$ depth, litter removed) and mixed to form a single sample per plot in order to reduce the soil heterogeneity. They were dried at laboratory temperature, crushed and passed through a $2 \mathrm{~mm}$ sieve. Soil acidity $(\mathrm{pH})$ was measured with the equipment WTW Inolab pH 720 in distilled water (1:2.5 soil:water ratio) and $\mathrm{C} / \mathrm{N}$-ratio with NCS-FLASH 1112 analyser. Determination of exchangeable cations $\left(\mathrm{Ca}^{2+}\right)$ in the soil samples were stated after extraction in a 
0.1 $\mathrm{M} \mathrm{BaCl}_{2}$-solution (Mehlich II) using an Atomic Absorption Spectrometer (AAS). In addition, soil profiles of individual vegetation types were made in September 2009 for description of morphological features and for determination of soil types. They were classified using the Slovak Soil Classification System (Sobocká 2000) in terminology of the World Reference Base for Soil Resources (ISSS-ISRIC-FAO 1998).

The nomenclature of non-vascular and vascular plants follows the checklist by Marhold \& Hindák (1998), and the syntaxa names are in accordance with Jarolímek et al. (2008a).

\section{RESULTS AND DISCUSSION}

Numerical classification distinguished four main groups of relevés according to their floristic similarity (Figure 2). They represent acidophilous, mesophilous and thermophilous oak vegetation corresponding to the four associations within classes of deciduous forests Quercetea roboripetraeae and Querco-Fagetea. Their syntaxonomical position is as follows:
Class: Quercetea robori-petraeae Br.-Bl. et R. Tx. ex Oberd. 1957

Order: Quercetalia roboris R. Tx. 1931

Alliance: Genisto germanicae-Quercion Neuhäusl et Neuhäuslová-Novotná 1967

Association: Luzulo albidae-Quercetum petraeae Hilitzer 1932

Class: Querco-Fagetea Br.-Bl. et Vlieger in Vlieger 1937

Order: Fagetalia Pawłowski in Pawłowski et al. 1928

Alliance: Carpinion betuli Issler 1931

Association: Melico uniflorae-Quercetum petraeae Gergely 1962

Order: Quercetalia pubescenti-petraeae Klika 1933

Alliance: Quercion confertae-cerris Horvat 1954

Association: Poo nemoralis-Quercetum dalechampii Šomšák et Háberová 1979

Alliance: Quercion petraeae Zólyomi et Jakucs ex Jakucs 1960

Association: Sorbo torminalis-Quercetum Svoboda ex Blažková 1962

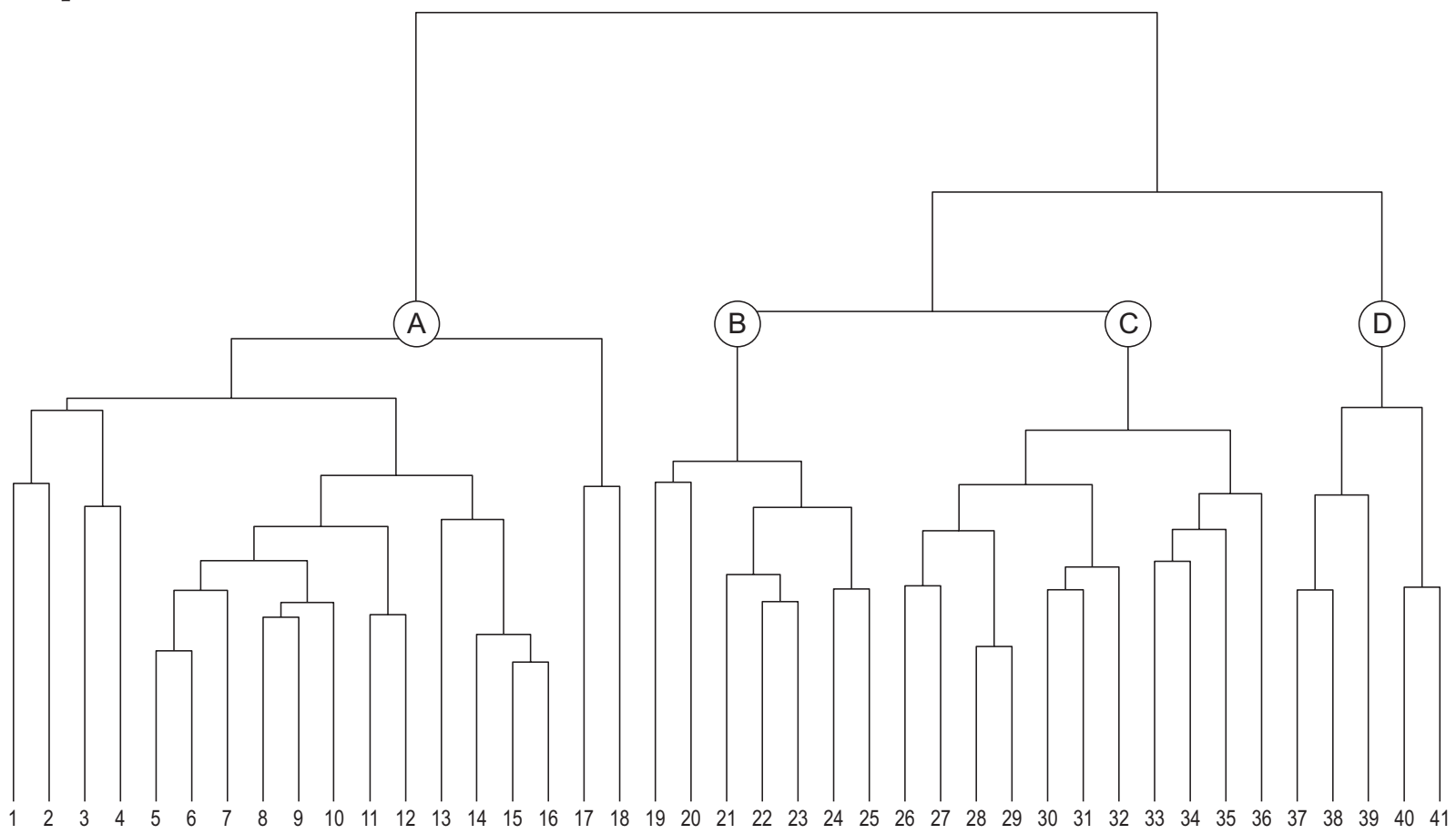

Figure 2: Dendrogram of numerical classification of oak forest vegetation in the northern part of the Štiavnické vrchy Mts (Cluster A - Luzulo albidae-Quercetum petraeae, B - Melico uniflorae-Quercetum petraeae, C - Poo nemoralis-Quercetum dalechampii, D - Sorbo torminalis-Quercetum).

Slika 2: Dendrogram numerične klasifikacije hrastovih gozdov severnega dela gorovja Štiavnické vrchy (Klaster A - Luzulo albidae-Quercetum petraeae, B - Melico uniflorae-Quercetum petraeae, C - Poo nemoralis-Quercetum dalechampii, D - Sorbo torminalis-Quercetum). 
The data set of 41 relevés comprises 178 vascular plants and 34 bryophytes. The most common herb species recorded in more than $70 \%$ of relevés were generalists of oak forest habitats such as Poa nemoralis, Galium schultesii, Veronica chamaedrys and a bryophyte Hypnum cupressiforme.

\section{Syntaxonomy and Site ECology}

Luzulo albidae-Quercetum petraeae (Cluster A, Table 1 , relevés $1-18$ )

This community represents acidophilous oak forests preferring moderately canopy-opened stands with shallow and mineral-poor soils (distric cambisols) at altitudes of 330-670 m. Moreover, in some places, mainly on steep slopes, the organic matter can be blown away and it causes nutrient depletion of the soils. Distribution is confined to small patches, primarily at ridge parts and convex spots. The simple vertical structure and the regular occurrence of oligotrophic and oligo-mesothrophic vascular plants (e.g. Genista pilosa, G. tinctoria, Hieracium lachenalii, $H$. sabaudum, Veronica officinalis), along with local admixture of thermophilous ones (Cardaminopsis arenosa, Hylotelephium maximum and Lembotropis nigricans), are typical features of this community. The shrub layer is generally formed only of young trees. In most cases, the herb layer is dominated by $\mathrm{Lu}$ zula luzuloides, seldom also by the narrow-leaved grass Avenella flexuosa. The peculiar feature of the species composition is a higher presence and coverage of mosses in comparison with the other detected oak vegetation types (Table 1). It is usually composed of common acidic-tolerant species including Ceratodon purpureus, Dicranum scoparium, Hypnum cupressiforme, Polytrichum formosum and $P$. piliferum. The proportion and the total spectrum of non-vascular plants coincide with the previous findings (Moravec 1998) as well as with a broad comparative study of European acidic woodlands (Härdtle 2004). In Slovakia, analogous communities with similar floristical structure are chiefly known from foothills of the Western Carpathians, less often from Inner-Carpathian basins (Slezák 2010).

Neuhäusl \& Neuhäuslová-Novotná (1967) revised the previous classifications (e.g. Mráz 1957) and introduced a new division of association into the Luzulo albidae-Quercetum typicum Mráz 1957 and Luzulo albidae-Quercetum genistetosum tincto- riae Samek ex Neuhäusl et Neuhäuslová-Novotná 1967 subassociations. Outside Slovakia, this syntaxonomical concept is broadly accepted in adjacent countries (Moravec 1998, Willner \& Grabherr 2007, Matuszkiewicz 2008).

Acidophilous oak and mixed oak deciduous forests are a typical vegetation type on acidic geological substrates in the colline and submontane belt of the sub-continental part of Europe. Their ecological singularity is emphasized through the specific site conditions, i.e. presence of skeletal soils with low nutrient supply (Neuhäusl \& Neuhäuslová-Novotná 1967, Slezák \& Kukla 2009a) and the litter removing (e.g. forest grazing) promoting their acidification (Šilc et al. 2008). The coverage of species-poor herb layer is markedly determined by the canopy structure. Therefore the species composition is created particularly by light-demanding species with the affinity to acidic habitats. The recent occurrence of some associations (e.g. Vaccinio vitis-ideae-Quercetum Oberd. 1957, Viscario-Quercetum Stöcker 1965) is limited due to lack of suitable sites and their change to pine or larch plantation (cf. Moravec 1998). Studies of acidophilous Quercus petraea agg. forests have had a long history in various European countries (Härdtle 2004), but their syntaxonomical position is not consistent. They are classified within the Querco-Fagetea class (e.g. Solomakha 1996, Willner \& Grabherr 2007) or within the separate class Quercetea robori-petraeae (e.g. Jarolímek et al. 2008a).

Melico uniflorae-Quercetum petraeae (Cluster B, Table 1, relevés 19-25)

The cluster B includes broad-leaved mixed oak forests occupying gentle and south-facing slopes on deeper luvi-cambisols in the submontane belt (420-805 m a.s.l.). It represents the Melico uniflorae-Quercetum petraeae association, which was first described by Gergely (1962) from the Mții Trascăului Mts in Romania. The stands are characterized by co-dominance of Quercus petraea agg. and Carpinus betulus in the tree layer and the prevalence of Melica uniflora in the herb layer. The shrub and moss layers are poorly developed. This community with relatively low floristical variability is clearly distinct from the other clusters. It belongs to the transition type between mesophilous oak-hornbeam and xerophilous oak forests (cf. Šomšák \& Háberová 1979). It is well-differenti- 
ated through the presence of numerous mesophilous and shade-tolerant species ranked into the Carpinion betuli alliance and Fagetalia order (Dactylis polygama, Galium odoratum, Geum urbanum, Neottia nidus-avis, Pulmonaria obscura, Symphytum tuberosum, Viola collina, V. reichenbachiana). The frequent abundance of Poa nemoralis reflects more opened sites with skeletal soils. Except for the Hieracium sabaudum and Luzula luzuloides, the acidophilous species are completely missing (Table 1). Several flora elements including Alliaria petiolata, Geranium robertianum, Glechoma hirsuta and Mercurialis perennis indicate a relatively baserich habitat with good mineralization of humus. Although the species composition conventionally comprises the thermophilous plants (e.g. Fragaria moschata, Clinopodium vulgare, Lathyrus niger), this association is rather close to the Carpinion betuli alliance.

Mesophilous broad-leaved oak-hornbeam forests are important elements of the Western Carpathian forest vegetation (Michalko 1991). Communities that are assigned to this alliance prefer low-altitudinal areas with subcontinental climate on mesotrophic to eutrophic soils (Knollová \& Chytrý 2004). The above mentioned ecological conditions are typical for some Slovak mountain units (e.g. Drienčanský kras Mts, Slovenský kras Mts, Vihorlatské vrchy Mts), where the Melico uniflorae-Quercetum petraeae is considered as common forest vegetation. Within the ecological range of the Carpinion betuli vegetation, it displays certain differences in terms of the stand structure, floristic composition and overall physiognomy (cf. Michalko 1957, Neuhäuslová-Novotná 1965, Moravec et al. 2000).

Poo nemoralis-Quercetum dalechampii (Cluster C, Table 1, relevés 26-36)

The community settles temperate slopes on distric cambisols with elevation range from $380 \mathrm{~m}$ to $694 \mathrm{~m}$ a.s.l. The partially mesophilous character of the stands is fully reflected in the species composition (Table 1). The uniformity of tree layer is expressed by the absolute dominance of Quercus petraea agg. Other woody species such as Carpinus betulus and Quercus cerris are only accompanying. The shrub layer with low coverage is constantly developed. Apart from Acer campestre, the typical shrubs are absent. Besides the dominance of medium-tall grass Poa nemoralis and a significant number of generalists of mesic forest habitats (Alliaria petiolata, Campanula rapunculoides, Galium schultesii, Melica uniflora and Veronica chamaedrys), the characteristic feature of the herb layer is the occurrence of several thermophilous species (Astragalus glycyphyllos, Clinopodium vulgare, Fragaria moschata). The beech forest herbs (Dentaria bulbifera and Tithymalus amygdaloides) along with Carex muricata agg., Cruciata glabra and Dryopteris filix-mas enrich the floristic spectrum. The participation of some acidophytes and acidic-tolerant species including Luzula luzuloides, Hypnum cupressiforme and Hedwigia ciliata is also constant. Consequently, the species composition, predominantly the abundant group of more nutrientdemanding species supports assignment of the Poo nemoralis-Quercetum dalechampii to the order Fagetalia. The present finding corresponds with a previous study by Kliment \& Watzka (2000), where it was placed into the Carpinion betuli alliance. By contrast, it has been ranked into the order Quercetalia pubescenti-petraeae following the contemporary national checklist of vegetation units (Jarolímek et al. 2008a), and equally the original description of the association (cf. Šomšák \& Háberová 1979). The missing comprehensive revision of oak forest communities and mainly the great variability of the species composition has probably led to the syntaxonomical differences as for classification at the level of higher vegetation units (alliance, order).

Accessible data about the Quercion confertaecerris alliance are concentrated to warm and dry areas of Slovakia, but the alliance does also rarely occur in some relatively cooler parts of the country, too (Neuhäusl \& Neuhäuslová-Novotná 1964, Neuhäuslová-Novotná \& Neuhäusl 1965, Neuhäuslová-Novotná 1968, Michalko 1991, Kliment \& Watzka 2000). The Poo nemoralis-Quercetum dalechampii represents the most mesic forest type in comparison with the other related associations of the same syntaxonomic affiliation (Carici montanae-Quercetum petraeae Gergely 1962, Quercetum petraeae-cerris Soó 1957, partially Potentillo albaeQuercetum Libbert 1933 and Sorbo torminalis-Quercetum). In addition to its typical aspect (the Poo nemoralis-Quercetum dalechampii typicum subassociation), Šomšák \& Háberová (1979) proposed the assignment of the stands with higher cover of the grass species Luzula luzuloides and constant occurrence of Platanthera bifolia, Steris viscaria and a bryophyte Polytrichum formosum to the new subassociation Poo nemoralis-Quercetum da- 
lechampii luzuletosum. The latter is characterized by the lower presence of some thermophilous herbs and absence of sunny-slope species (Lactuca quercina and Vicia tenuifolia). Due to the small number of relevés from the geographically limited area (Slovenský kras Mts), this classification needs to be revised. Similar oak habitats were formerly classified as the subassociation Querco petraeae-Carpinetum Soó et Pócs (1931) 1957 poetosum nemoralis (Mikyška 1939) Klika 1951 (e.g Michalko 1957, Balkovič 2002).

Sorbo torminalis-Quercetum (Cluster D, Table 1, relevés 37-41)

The thermophilous oak forests of slightly acidic substrates on distric cambisol build open to moderately closed stands on south-facing slopes in the submontane belt (390-540 m a.s.l.). Quercus petraea agg. and Q. cerris alternate as dominants of the tree layer, while Sorbus torminalis and Carpinus betulus with a lower coverage are admixed only individually. Due to favourable light conditions, the shrub layer has been usually developed, and encompasses thermophilous shrubs (Ligustrum vulgare and Cornus mas) together with saplings of Sorbus torminalis and Quercus petraea agg. The grassy physiognomy of the species-rich herb layer resulted from the dominance of Poa nemoralis, Brachypodium pinnatum and the local presence of Festuca heterophylla and F. pseudodalmatica. Except for the common dry-mesic forest species and acidic-tolerant ones (Cardaminopsis arenosa, Clinopodium vulgare, Galium glaucum, Genista pilosa, G. tinctoria, Hylotelephium maximum, Pyrethrum corymbosum, Silene nutans), the herb layer is enriched by facultative calciphyte Campanula persicifolia and mesophilous species such as Dactylis polygama and Galium schultesii (cf. Chytrý \& Horák 1997). However, the conspicuous aspect is formed by both plants of dry grasslands and forests fringes, including Dianthus carthusianorum, Origanum vulgare, Teucrium chamaedrys, Tithymalus cyparissias, Trifolium aplestre and Verbascum chaixii subsp. austriacum. In the moss layer were found Atrichum undulatum, Bryum capillare, Hypnum cupressiforme and Weissia controversa.

These forests exhibit similarities to the thermophilous turkey oak forests on mineral-rich soils included in the association Quercetum petraeae-cerris, primarily to the Poa nemoralis variant containing more mesic flora elements (cf. Roleček 2005). The partial differences have been observed in the abundance of thermophilous plants; several of them are missing (e.g. Filipendula vulgaris, Fragaria viridis, Rosa gallica) or else manifest a lower frequency (e.g. Lychnis coronaria, Vicia cassubica) in our data set (Table 1). On the other hand, numerous plants with close relation to the sunny and drier sites have their ecological optimum in this alliance. Up to now, the Central European thermophilous oak forests of Sorbo torminalisQuercetum have been known from the Bohemian Massif and Moravia region in the Czech Republic, from where they have extended to northern Austria (Chytrý 1997). In the last decade, this association has been reported from Poland as well (Kwiatkowski 2003, Bednorz 2007).

Neuhäusl \& Neuhäuslová-Novotná (1964) documented an other two oak woodlands in the southern part of the Štiavnické vrchy Mts; canopy-opened oak forests with Carpathian sub-endemic tall grass Poa pannonica subsp. scabra (Poo scabrae-Quercetum (Magyar 1933) Neuhäusl et Neuhäuslová-Novotná 1964) and sub-xerophilous forests of sunny slopes (Festuco heterophyllae-Quercetum Neuhäusl et Neuhäuslová-Novotná 1964). Because of their obvious relation to arid stands in the colline belt, it was not possible to find these distinctive communities in the more humid and cooler northern part of the mountain unit.

\section{SOIL PROFILES DESGRIPTION}

The morphological description of soil pits provides some insights into the impact of soil physical structure on vegetation. From the individual soil profiles, there have been deduced some general characteristics for the associated oak vegetation types: 1) the forests have been developed on shallow to medium deep cambisols; 2) the content of rock fragments is very variable; 3 ) for the individual vegetation types, the soil texture is relatively homogeneous throughout the profile; 4) the whole soil profile is biologically active down to the parent material (see root system).

In general, the soil water (its forms, amount and tenacity) serves a central role in a number of processes occurring in soils, and therefore influences the plant community composition and its physiognomy. Its status is directly linked to the soil depth and texture (along with the location in landscape and the seasonal partitioning of rainfalls). The shallow and very skeletal soils have a lower water-holding capacity (cf. Lavelle \& Spain 
2003). This leads to periodic soil water-deficit mainly for elements of the tree layer. These stands are occupied by more canopy-opened forests ( $\mathrm{Lu}$ zulo albidae-Quercetum petraeae and Sorbo torminalis-Quercetum) with species having higher requirements on the light conditions and tolerance to drought. Vegetation of the alliances Carpinion betuli and Quercion confertae-cerris established on the deeper soils has a surface rich in organic matter. The favourable conditions are also reflected in the global floristic composition (higher presence of nutrient-demanding and shade-tolerant species; Table 1).

\section{Ass.: Luzulo albidae-Quercetum petraeae}

Bedrock (Quartzite); Soil subtype (Dystric-Cambisol); Position (relevé no. 17); Horizons:

Ool 2-1 cm, dry grasses, oak foliage and twigs

Oof 1-0 cm, mostly oak foliage together with dry grasses

Aoq 0-4 cm, dark brown (7.5YR 3/4) sandy loam, fresh moist, fine granular structure, loose consistent, many fine roots, rock fragments (30 $\%)$, clear wavy boundary to next horizon

Bv 4-20 cm, yellowish brown (10YR 5/4) silty loam, fresh moist, medium granular structure, medium firm consistent, many fine roots, rock fragments (45\%), gradual transition to next horizon

B/C 20-40 cm, yellowish brown (10YR 5/6) silty loam, fresh moist, medium granular structure, firm consistent, common fine roots, rock fragments (65\%)

$\mathrm{C}_{1} 40+\mathrm{cm}$, silicate parent material

\section{Ass.: Melico uniflorae-Quercetum petraeae}

Bedrock (Andesites); Soil subtype (Luvi-Cambisol); Position (relevé no. 24); Horizons:

Ool 3-1 cm, oak and oak-hornbeam litter

Oof $1-0 \mathrm{~cm}$

Aoq 0-2 cm, dark brown (7.5YR 3/4) silty loam, moist, fine to medium granular structure, loose consistent, many fine roots, rock fragments (0 \%), clear smooth boundary to next horizon

$\mathrm{Bv}_{1}$ 2-30 cm, light brown (7.5YR 6/3) silty loam, fresh moist, fine subangular blocky structure, medium firm consistent, common fine roots, rock fragments $(0 \%)$, diffuse boundary to next horizon

Bvt $30-60 \mathrm{~cm}$, light brownish grey (10YR 6/2) silty loam, fresh moist, subangular blocky structure, firm consistent, common fine roots, rock fragments (10\%), gradual transition to next horizon

B/C 60-75+ cm, light brownish grey (10YR 6/2) silty loam, fresh moist, subangular blocky structure, firm consistent, few fine roots, rock fragments $(65 \%)$

\section{Ass.: Poo nemoralis-Quercetum dalechampii}

Bedrock (Andesites); Soil subtype (Dystric-Cambisol); Position (relevé no. 26); Horizons:

Ool 5-3 cm, oak litter

Oof $3-0 \mathrm{~cm}$, partially decomposed oak litter and dry grasses

Aoq 0-5 cm, dark brown (7.5YR 3/4) silty loam, fresh moist, fine to medium granular structure, loose to friable consistent, many fine roots, rock fragments (10\%), clear wavy boundary to next horizon

$\mathrm{Bv}_{1}$ 5-25 cm, brown (7.5YR 5/3) silty loam, fresh moist, medium granular structure, medium firm consistent, many fine roots, rock fragments (20\%), gradual transition to next horizon

$\mathrm{Bv}_{2} 25-55 \mathrm{~cm}$, light brown (7.5YR 6/3) silty loam, fresh moist, fine subangular blocky structure, firm consistent, common fine roots, rock fragments (40\%), gradual transition to next horizon

B/C 55-80 cm, light brownish grey (10YR 6/2) silty loam, fresh moist, subangular blocky structure, very firmly consistent, few fine roots, rock fragments (70\%)

$\mathrm{C}_{1} 80+\mathrm{cm}$, silicate parent material

\section{Ass.: Sorbo torminalis-Quercetum}

Bedrock (Andesites); Soil subtype (Dystric-Cambisol); Position (relevé no. 37); Horizons:

Ool 4-2 cm, dry grasses, oak foliage and twigs

Oof $2-0 \mathrm{~cm}$, mostly oak foliage

Aoq 0-2 cm, dark brown (7.5YR 3/4) silty loam, fresh moist, fine granular structure, loose consistent, many fine roots, rock fragments ( $<5 \%)$, clear wavy boundary to next horizon

Bv 2-20 cm, greyish brown (10YR 5/2) silty loam, fresh moist, medium to coarse granular soil structure, medium firm consistent, many fine roots, rock fragments (20\%), gradual transition to next horizon

B/C 20-55 cm, greyish brown (10YR 5/2) silty loam, fresh moist, medium to coarse granular soil structure, firm consistent, common fine roots, rock fragments (70\%)

$\mathrm{C}_{1} 55+\mathrm{cm}$, silicate parent material 


\section{MAin ENVIRONMENTAL GRADIENT}

The vegetation-environment relationships are displayed on the DCA ordination diagram (Figure 3). The DCA analysis revealed a clear floristical and ecological separation of the individual vegetation types within the ordination space. The main gradient expresses the combination of the soil reaction and available nutrients in the soil following the Ellenberg indicator values (1. axis). This could be explained by their mutual correlation (cf. Härdtle et al. 2003, 2005, Schuster \& Diekmann 2005). Along this nutrient poor-rich-gradient, the vegetation plots are ordered from forests of acidic stands to forests closely related with slightly acidic and neutral habitats. Accordingly, the right part of the scatter-plot is occupied by the relevés of the Luzulo albidae-Quercetum petraeae, preferring shallow and acidic soils with low nutrient content. The most mesophilous forests, having most

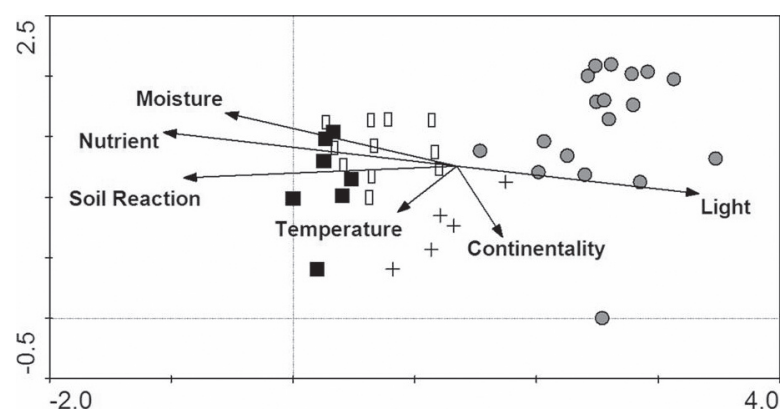

Figure 3: DCA ordination diagram of the oak forest vegetation samples with Ellenberg indicator values as supplementary variables (length of gradient 3.471; eigenvalues of the first two axes are 0.501 and 0.231 ; total inertia 4.234). Shaded circles - Luzulo albidae-Quercetum petraeae, full squares - Melico uniflorae-Quercetum petraeae, crosses Sorbo torminalis-Quercetum, empty rectangles - Poo nemoralis-Quercetum dalechampii. Correlations between first two axes and environmental variables: Light (0.780 and 0.132), Continentality (0.115 and -0.231$)$, Temperature $(-0.217$ and $-0.237)$, Soil Reaction ( -0.902 and -0.315$)$, Nutrient $(-0.945$ and -0.158$)$, Moisture $(-0.732$ and -0.022$)$.

Slika 3: Diagram DCA ordinacije popisov hrastovih gozdov z Ellenbergovimi indikatorskimi vrednostmi kot dodatnimi spremenljivkami (dolžina gradienta 3,471; lastne vrednosti prvih dveh osi 0,501 in 0,231 ; variabilnost vseh ordinacijskih osi 4,234). Zasenčeni krožci - Luzulo albidae-Quercetum petraeae, polni kvadratki - Melico uniflorae-Quercetum petraeae, križci - Sorbo torminalis-Quercetum, prazni pravokotniki - Poo nemoralis-Quercetum dalechampii. Korelacija med prvima dvema osema in okoljske spremenljivke: svetloba $(0,780$ in 0,132$)$, kontinentalnost $(0,115$ in $-0,231)$, toplota $(-0,217$ in $-0,237)$, reakcija tal $(-0,902$ in $-0,315)$, hranila $(-0,945$ in $-0,158)$, vlažnost $(-0,732$ in $-0,022)$. favourable edaphic conditions (Melico unifloraeQuercetum petraeae), dominate the opposite part. Moreover, light belongs to the environmental variables displaying a strong positive correlation. In this sense, the communities are arranged from more or less shaded to the canopy-opened ones. These general patterns of floristic variation were also emphasized by DCA analysis of the measured parameters (Figure 4). The first ordination axis was highly positively correlated with $\mathrm{C} / \mathrm{N}$-ratio and negatively correlated with soil reaction $(\mathrm{pH})$.

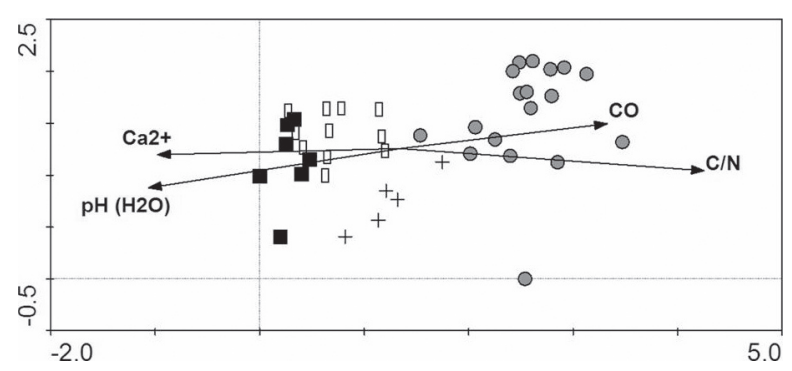

Figure 4: DCA ordination diagram of both samples and measured environmental variables: soil reaction $(\mathrm{pH})$, calcium $\left(\mathrm{Ca}^{2+}\right), \mathrm{C} / \mathrm{N}$-ratio, canopy openness (CO). Correlations between the first two axes and environmental variables: $\mathrm{pH}$ $(-0.715$ and -0.339$), \mathrm{Ca}^{2+}(-0.676$ and -0.223$), \mathrm{C} / \mathrm{N}(0.833$ and 0.180$)$, CO (0.584 and 0.253$)$. For explanation of the symbols of vegetation types see Figure 3.

Slika 4: Diagram DCA ordinacije vzorcev in merjenih okoljskih spremenljivk: reakcija tal $(\mathrm{pH}), \operatorname{kalcij}\left(\mathrm{Ca}^{2+}\right), \mathrm{C} /$ $\mathrm{N}$ razmerje, odprtost sklopa (CO). Korelacija med prvima dvema osema in okoljskimi spremenljivkami: $\mathrm{pH}(-0,715$ in $-0,339), \mathrm{Ca}^{2+}(-0,676$ in $-0,223), \mathrm{C} / \mathrm{N}(0,833$ in 0,180$)$, $\mathrm{CO}(0,584$ in 0,253$)$. Za razlago simbolov vegetacijskih tipov glej Sliko 3.

The study supported the relevance of soil and light conditions as determinants affecting the species composition of deciduous forests. The water availability and the other just discussed factors have been confirmed by controlling the vegetation distribution at local and/or regional level (e.g. Kanka 2001, Härdtle et al. 2005, Wallnöfer \& Hotter 2008, Slezák \& Kukla 2009a), while the geographical gradient has been found significant at large-scale (cf. Knollová \& Chytrý 2004).

\section{ACKNOWLEDGEMENTS}

We would like to thank Ján Kukla for assistance during the fieldwork, Milan Štech for revision of specimens of Festuca pseudodalmatica, Achillea nobilis, Richard Hrivnák and two anonymous 
reviewers for useful comments on this paper. We are also grateful to Daniela Dúbravková for language correction and Dušan Senko for help with preparing the map. The research was supported by the Scientific Grant Agency of the Ministry of Education of Slovak Republic and the Slovak Academy of Sciences VEGA (Project No. 2/0034/10) and the University Grant Agency UMB in Banská Bystrica UGA UMB (Project No. I-09-000-27).

\section{REFERENCES}

Balkovič, J. 2002: Forest vegetation in the northwestern part of the Štiavnické vrchy Mts. Phytopedon 2002 (1): 17-32.

Barkman, J. J., Doing, H. \& Segal, S. 1964: Kritische Bemerkungen und Vorschläge zur quantitativen Vegetationsanalyse. Acta Botanica Neerlandica 13: 394-419.

Bednorz, L. 2007: The wild service tree Sorbus torminalis (L.) Crantz in plant communities of Poland. Dendrobiology 57: 49-54.

Botta-Dukát, Z., Chytrý, M., Hájková, P. \& Havlová, M. 2005: Vegetation of lowland wet meadows along a climatic continentality gradient in Central Europe. Preslia 77: 89-111.

Chytrý, M. 1994: Xerothermic oak forests in the middle Váh basin and the southern part of the Strážovská hornatina upland, Slovakia. Scripta-Biology 22-23: 121-134.

Chytrý, M. 1997: Thermophilous oak forests in the Czech Republic: syntaxonomical revision of the Quercetalia pubescenti-petraeae. Folia Geobotanica et Phytotaxonomica 32: 221-258.

Chytrý, M. \& Horák, J. 1997: Plant communities of the thermophilous oak forests in Moravia. Preslia 68: 193-240.

Chytrý, M., Tichý, L., Holt, J. \& Botta-Dukát, Z. 2002: Determination of diagnostic species with statistical fidelity measures. Journal of Vegetation Science 13: 79-90.

Ellenberg, H. 1982: Vegetation Mitteleuropas mit den Alpen. Ulmer, Stuttgart, 989 pp.

Ellenberg, H., Weber, H. E., Düll, R., Wirth, W., Werner, W. \& Paulißen, D. 1992: Zeigerwerte von Pflanzen in Mitteleuropa. Scripta Geobotanica 18: 1-258.

Franjić, J., Liber, Z., Škvorc, Ž., Idžojtić, M., Šoštarić, R. \& Stančić, Z. 2006: Morphological and molecular differentiation of the Croa- tian populations of Quercus pubescens Willd. (Fagaceae). Acta Societatis Botanicorum Poloniae 75: 123-130.

Frazer, G. W., Canham, C. D. \& Lertzman, K. P. 1999: Gap Light Analyzer (GLA), Version 2.0. Imaging software to extract canopy structure and gap light transmission indices from truecolour fisheye photographs, user's manual and program documentation. Simon Fraser University, Burnaby, British Columbia, 36 pp.

Gergely, I. 1962: Contribuții la studiul fitocenologic al pădurilor din partea nordică a Munților Trascăului. Contributii Botanice (Cluj) 1962: 263-298.

Gömöry, D., Yakovlev, I., Zhelev, P., Jedináková, J. \& Paule, L. 2001: Genetic differentiation of oak populations within the Quercus robur/Quercus petraea complex in Central and Eastern Europe. Heredity 86: 557-563.

Härdtle, W. 2004: Bodensaure Eichen- und Eichenmischwälder Europas. Tuexenia 24: 57-72.

Härdtle, W., von Oheimb, G. \& Westphal, C. 2003: The effects of light and soil conditions on the species richness of the ground vegetation of deciduous forests in northern Germany (Schleswig-Holstein). Forest Ecology and Management 182: 327-338.

Härdtle, W., von Oheimb, G. \& Westphal, C. 2005: Relationships between the vegetation and soil conditions in beech and beech-oak forests of northern Germany. Plant Ecology 177: 113-124.

Hennekens, S. M. \& Schaminée, J. H. J. 2001: TURBOVEG, a comprehensive data base management system for vegetation data. Journal of Vegetation Science 12: 589-591.

Hrivnák, R., Hájek, M., Blanár, D., Kochjarová, J. \& Hájková, P. 2008: Mire vegetation of the Muránska Planina Mts - formalised classification, ecology, main environmental gradient and influence of geographical position. Biologia (Bratislava) 63: 368-377.

ISSS-ISRIC-FAO 1998: World Reference Base for Soil Resources. World Soil Resources Reports 84: 1-92.

Jakucs, P. 1961: Die phytozönologischen Verhältnisse der Flaumeichen Buschwälder Südostmitteleuropas. Akadémiai Kiadó, Budapest, $316 \mathrm{pp}$.

Jarolímek, I., Šibík, J., Hegedüšová, K., Janišová, M., Kliment, J., Kučera, P., Májeková, J., Michálková, D., Sadloňová, J., Šibíková, I., Škodová, I., Uhlî́rová, J., Ujházy, K., Ujházy- 
ová, M., Valachovič, M. \& Zaliberová, M. 2008a: A list of vegetation units of Slovakia. In: Jarolímek, I. \& Śibík, J. (eds.): Diagnostic, constant and dominant species of the higher vegetation units of Slovakia. Veda, Bratislava, pp. 295-329.

Jarolímek, I., Šibík, J., Tichý, L. \& Kliment, J. 2008b: Diagnostic, constant and dominant species of the higher vegetation units of Slovakia. In: Jarolímek, I. \& Šibík, J. (eds.): Diagnostic, constant and dominant species of the higher vegetation units of Slovakia. Veda, Bratislava, pp. 9-294.

Jelaska, S. D. 2004: Analysis of canopy closure in the Dinaric silver fir-beech forests (OmphalodoFagetum) in Croatia using hemispherical photography. Hacquetia 3 (2): 43-49.

Jurko, A. 1965: Potentillo albae-Quercetum pri Prešove. Biologia (Bratislava) 20: 55-58.

Kanka, R. 2001: Phytocoenological characteristic of the thermophilous oak forests with Quercus pubescens agg. in the Malé Karpaty Mts, Slovakia. Biologia (Bratislava) 56: 85-101.

Klika,J.1937:XerothermeundWaldgesellschaften der Westkarpathen (Brezover Berge). Beihefte zum Botanischen Centralblatt 57: 295-342.

Kliment, J. \& Watzka, R. 2000: Lesné spoločenstvá Drienčanského krasu. In: Kliment, J. (ed.): Príroda Drienčanského krasu. ŠOP SR, Banská Bystrica, pp. 191-214.

Knollová, I. \& Chytrý, M. 2004: Oak-hornbeam forests of the Czech Republic: geographical and ecological approaches to vegetation classification. Preslia 76: 291-311.

Kwiatkowski, P. 2003: Podgórska ciepłolubna dąbrowa brekiniowa Sorbo torminalis-Quercetum na Pogórzu Złotoryjskim. Fragmenta Floristica et Geobotanica, Ser. Polonica 10: 175193.

Lavelle, P. \& Spain, A. V. 2003: Soil Ecology. Kluwer Academic Publishers, Dordrecht, 654 pp.

Magic, D. 2006: Quercus L. In: Goliašová, K. \& Michalková, E. (eds.): Flóra Slovenska V/3. Veda, Bratislava, pp. 108-143.

Marhold, K. \& Hindák, F. (eds.) 1998: Zoznam nižších a vyšších rastlín Slovenska. Veda, Bratislava, $688 \mathrm{pp}$.

Matuszkiewicz, W. 2008: Przewodnik do oznaczania zbiorowisk roślinnych Polski. Wydawnictwo Naukowe PWN, Warszawa, 542 pp.

Miadok, D. 1991: Xerotermofilné dubiny Koniarskej planiny. Biologia (Bratislava) 46: 451-462.
Michalko, J. 1957: Geobotanické pomery pohoria Vihorlat. Vydavatel'stvo SAV, Bratislava, 198 pp.

Michalko, J. 1991: Lesné spoločenstvá Košickej kotliny (so zretel'om na ostatné kotliny a prilahlé nížiny slovenských Karpát). Acta Botanica Slovaca, Ser. A 11: 9-135.

Michálková, D. 2007: Diversity of dry grasslands in the Považský Inovec Mts (Slovakia) - a numerical analysis. Hacquetia 6 (1): 61-76.

Moravec, J. 1998: Přehled vegetace České republiky, Svazek 1. Acidofilní doubravy. Academia, Praha, 64 pp.

Moravec, J., Husová, M., Chytrý, M. \& Neuhäuslová, Z. 2000: Přehled vegetace České republiky, Svazek 2. Hygrofilní, mezofilní a xerofilní opadavé lesy. Academia, Praha, 320 pp.

Mráz, K. 1957: Waldkundliche Untersuchungen im Mittelböhmischen Bergland und Erfahrungen mit der Anwendung statistischer Maschinen bei der synthetischen Bearbeitung. Archiv für Forstwesen 6 (2-3): 109-191.

Neuhäusl, R. \& Neuhäuslová-Novotná, Z. 1964: Vegetationsverhältnisse am Südrand des Schemnitzer Gebirges. Biologické Práce 10 (4): $1-80$.

Neuhäusl, R. \& Neuhäuslová-Novotná, Z. 1967: Syntaxonomische Revision der azidophilen Eichen- und Eichenmischwälder im westlichen Teile der Tschechoslowakei. Folia Geobotanica et Phytotaxonomica 2 (2): 1-41.

Neuhäuslová-Novotná, Z. 1965: Waldgesellschaften in der Gegend von Krupina (SSO-Slowakei). Biologické Práce 11 (9): 27-50.

Neuhäuslová-Novotná, Z. 1968: Beitrag zu den floristisch-phytozönologischen Verhältnissen der Gegend von Lučenec. Biologické Práce 14 (4): 5-70.

Neuhäuslová-Novotná, Z. \& Neuhäusl, R. 1965: Beitrag zur Kenntnis der Zerreichen-TraubenEichenwälder des Hügellandes Pohronská pahorkatina (S-Slowakei). Biologia (Bratislava) 20: 511-523.

Nixon, K. C. 1993: Infrageneric classification of Quercus (Fagaceae) and typification of sectional names. Annales des Sciences Forestières 50, Suppl. 1: 25-34.

Podani, J. 2001: SYN-TAX 2000. Computer Program for Data Analysis in Ecology and Systematics for Windows 95, 98 \& NT. User's manual. Scientia Publishing, Budapest, 53 pp.

Roleček, J. 2004: Subkontinentální doubravy asociace Carici fritschii-Quercetum roboris na Záhoří. 
Bulletin Slovenskej Botanickej Spoločnosti 26: 163-176.

Roleček, J. 2005: Vegetation types of dry-mesic oak forests in Slovakia. Preslia 77: 241-261.

Schuster, B. \& Diekmann, M. 2005: Species richness and environmental correlates in deciduous forests of Northwest Germany. Forest Ecology and Management 206: 197-205.

Slezák, M. 2010: Charakteristika asociácie Luzulo albidae-Quercetum petraeae v Štiavnických vrchoch (stredné Slovensko). Bulletin Slovenskej Botanickej Spoločnosti 32, (accepted).

Slezák, M. \& Hegedüšová, K. 2010: Fytocenologická charakteristika lesných spoločenstiev severnej časti Štiavnických vrchov. Bulletin Slovenskej Botanickej Spoločnosti, Suppl., (accepted).

Slezák, M. \& Kukla, J. 2009a: Forest vegetation of the northern part of the Štiavnické vrchy Mts. Folia Oecologica 36 (1): 39-49.

Slezák, M. \& Kukla, J. 2009b: Výskyt niektorých zriedkavejších cievnatých rastlín v severnej časti Štiavnických vrchov. Bulletin Slovenskej Botanickej Spoločnosti 31: 17-25.

Sobocká, J. (ed.) 2000: Morfogenetický klasifikačný systém pôd Slovenska. Bazálna referenčná taxonómia. VÚPOP, Bratislava, $76 \mathrm{pp}$.

Solomakha, V. A. 1996: The syntaxonomy of vegetation of Ukraine. Ukrainian Phytosociological Collection, Ser. A, 4 (5): 1-121.
Šilc, U., Čarni, A., Košir, P., Marinšek, A. \& Zelnik, I. 2008: Litter-ranking forests in SE Slovenia and in Croatia. Hacquetia 7 (1): 71-88.

Šomšák, L. 1963: Dubiny južnej časti Malej Fatry a ich ochrana. Československá ochrana prírody 1: 146-164.

Šomšák, L. \& Háberová, I. 1979: Die Waldgesellschaften des Silica-Plateaus. Biologické Práce 25 (2): 5-89.

ter Braak, C. J. F. \& Šmilauer, P. 2002: CANOCO Reference manual and CanoDraw for Windows User's guide. Software for Canonical Community Ordination (version 4.5). Microcomputer Power, Ithaca, NY, $500 \mathrm{pp}$.

Tichý, L. 2002: JUICE, software for vegetation classification. Journal of Vegetation Science 13: 451-453.

Tichý, L. \& Chytrý, M. 2006: Statistical determination of diagnostic species for site groups of unequal size. Journal of Vegetation Science 17: 809-818.

Wallnöfer, S. \& Hotter, M. 2008: Syntaxonomy and site ecology of mixed oak forest communities in the Inner and Intermedial Alps of Tyrol (Austria). Botanica Helvetica 118: 21-43.

Willner, W. \& Grabherr, G. 2007: Die Wälder und Gebüsche Österreichs. Ein Bestimmungswerk mit Tabellen. Spektrum Akademischer Verlag, Heidelberg, 302 pp. 


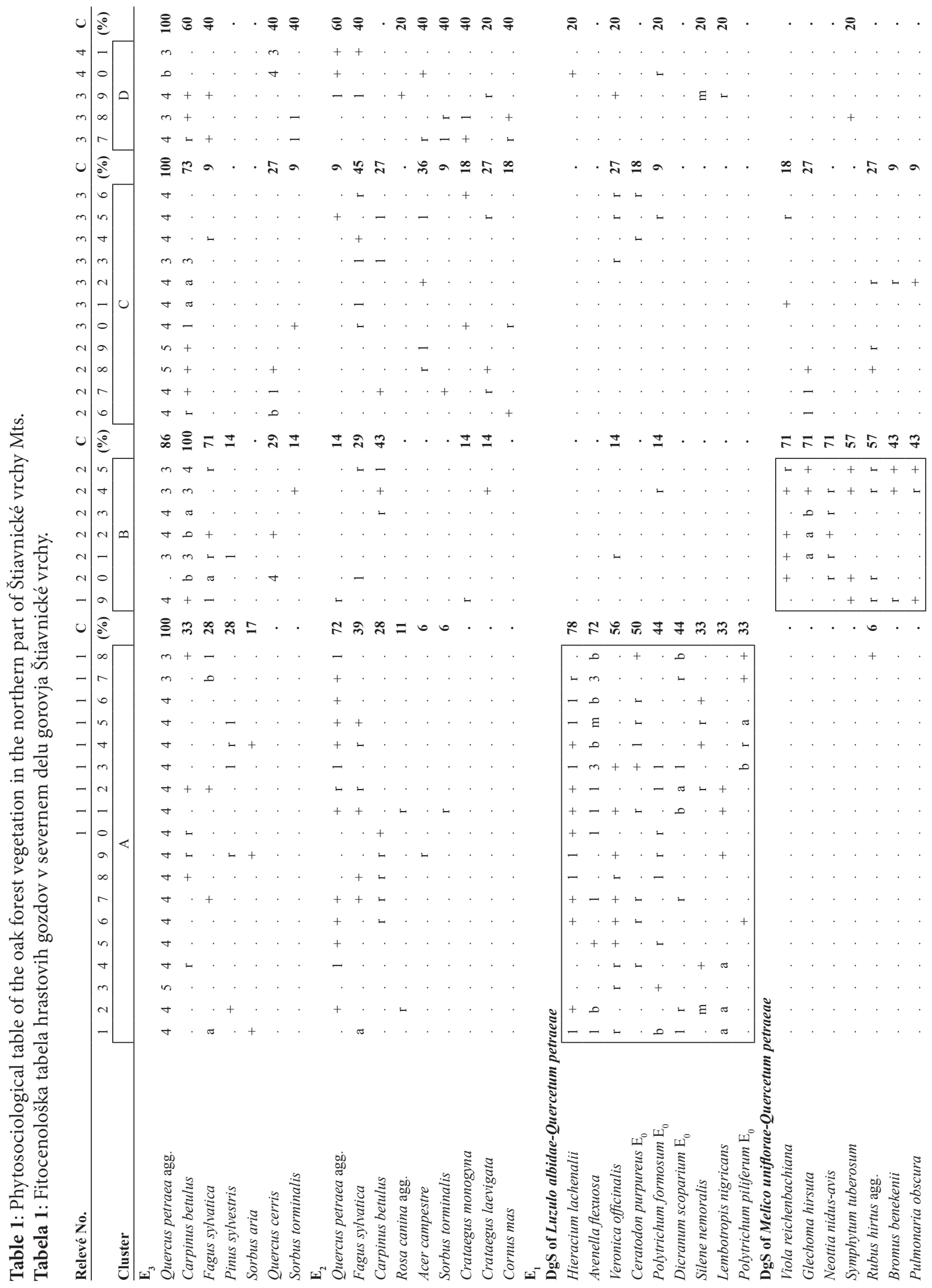




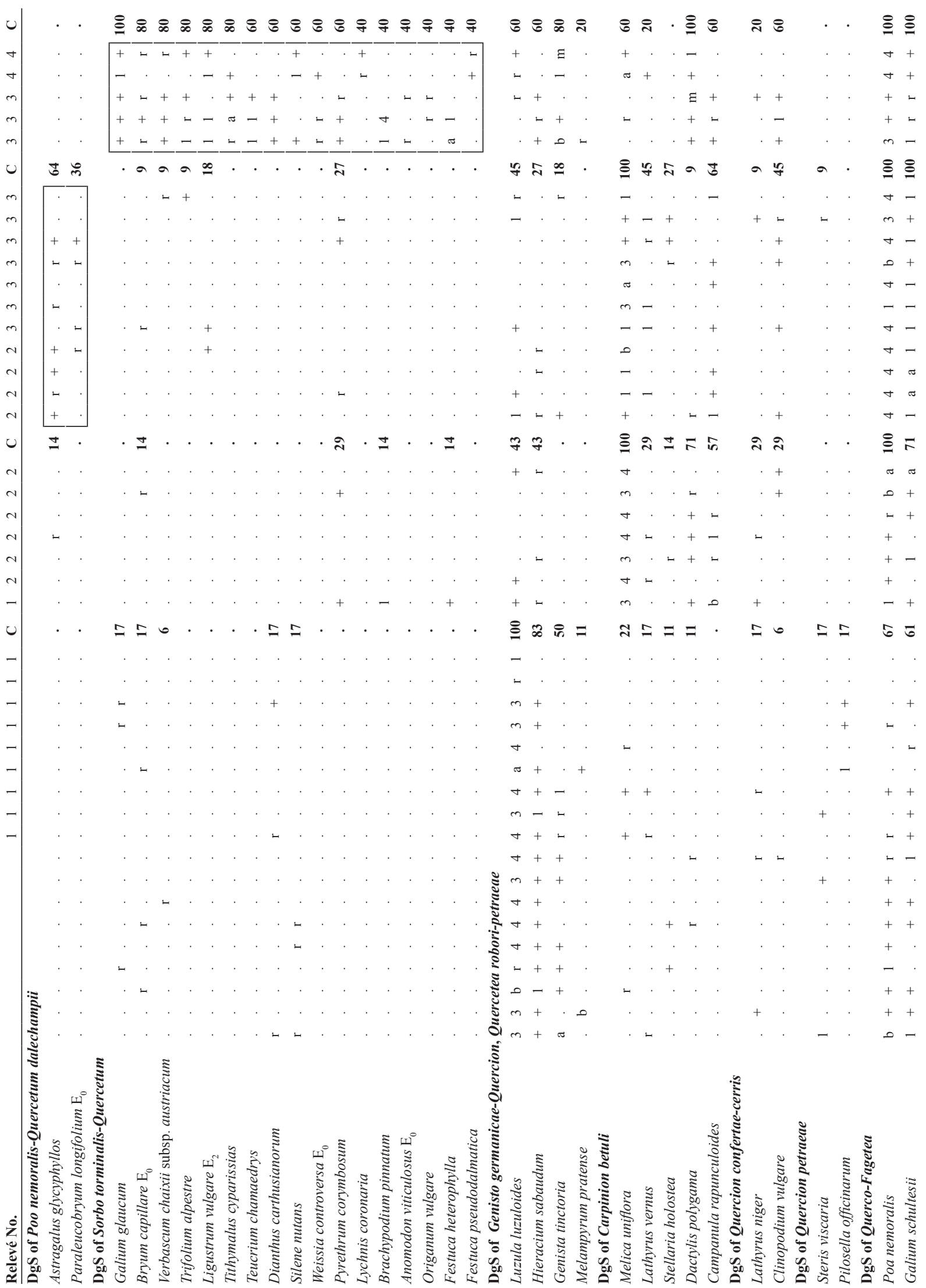



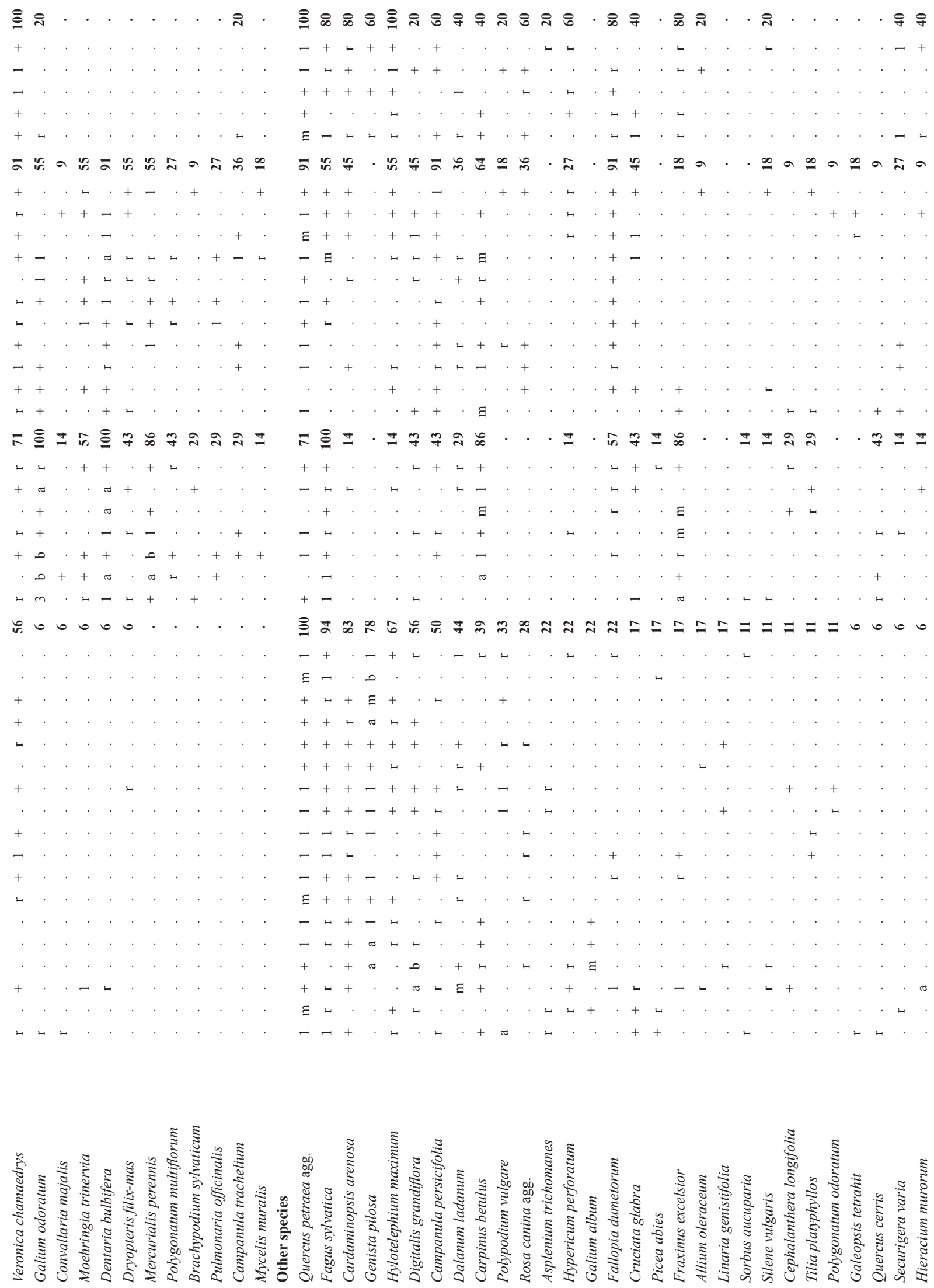


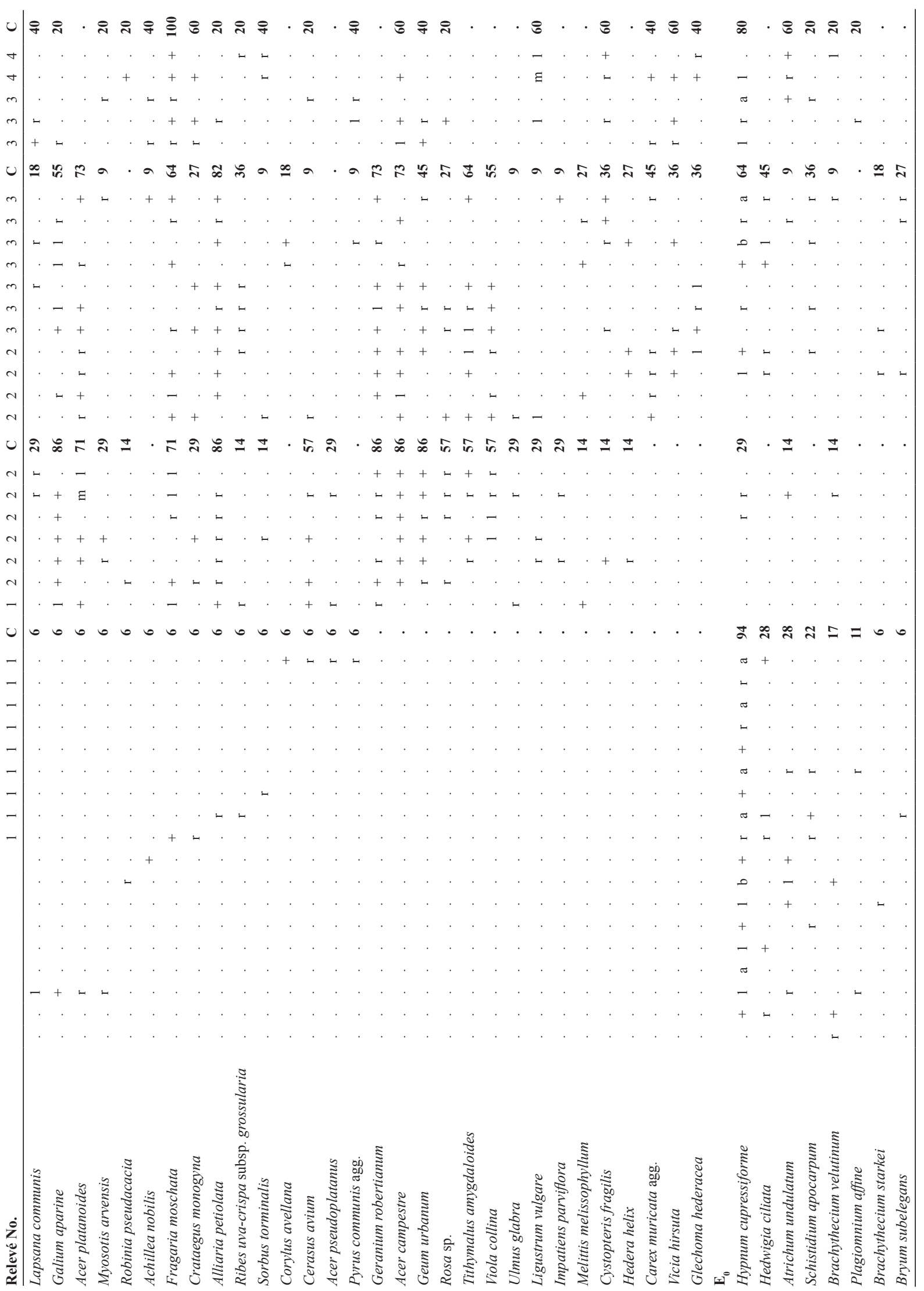




\section{Legend}

A - Luzulo albidae-Quercetum petraeae, B - Melico uniflorae-Quercetum petraeae, C - Poo nemoralis-Quercetum dalechampii, D - Sorbo torminalis-Quercetum, DgS - Diagnostic species.

Species present only in one or two relevés:

$\mathbf{E}_{3}$ - tree layer: Abies alba $(18,+)$, Acer campestre $(35,+; 38,+)$, A. platanoides $(21,+; 22,+)$, A. pseudoplatanus $(19, \mathrm{r})$, Betula pendula $(17, \mathrm{r})$, Cerasus avium $(18,+)$, Corylus avellana $(19, \mathrm{r} ; 34,+)$, Fraxinus excelsior $(19, \mathrm{a} ; 22,1)$, Larix decidua (17, a), Pinus nigra $(12,+)$, Sorbus aucuparia $(37,+)$, Tilia cordata $(1,+)$, T. platyphyllos $(35, \mathrm{r} ; 36,+)$.

$\mathbf{E}_{2}$ - shrub layer: Betula pendula $(17,+)$, Corylus avellana $(19, \mathrm{a} ; 25, \mathrm{r})$, Picea abies $(1,1 ; 17,+)$, Pinus sylvestris $(16, \mathrm{r})$, Pyrus communis agg. $(38,1)$, Ribes uva-crispa subsp. grossularia $(30,+)$, Robinia pseudacacia $(40,+)$, Rosa sp. $(18, \mathrm{r} ; 32, \mathrm{r})$, Sorbus aria $(36,+; 37$, $+)$, S. aucuparia $(37,+)$.

$\mathbf{E}_{1}$ - herb layer: Ajuga genevensis (36, r; 38, r), A. reptans (24, r; 33, r), Allium senescens subsp. montanum (37, +), Anthoxanthum odoratum ( $7, \mathrm{r} ; 13,1)$, Anthriscus cerefolium (22, r), A. sylvestris (20, r), Asarum europaeum $(25,+)$, Asplenium septentrionale (2, +; 36, r), Athyrium filix-femina (19, r), Betonica officinalis (19, r), Betula pendula (17, r), Calamagrostis arundinacea $(1,1 ; 19,1)$, Cardamine impatiens $(4, \mathrm{r})$, Carex pilosa $(21, \mathrm{~b} ; 30, \mathrm{r})$, Circaea lutetiana $(19, \mathrm{r})$, Cornus mas $(37,+)$, Crataegus laevigata $(24,+)$, Dactylis glomerata (12, r), Dorycnium herbaceum (37, r), Epilobium montanum (19, r), Epipactis helleborine (19, +), Erysimum odoratum (2, r), Fragaria vesca $(31,+; 32,1)$, Galeobdolon luteum $(23, \mathrm{r} ; 30,1)$, Galium verum $(2,+)$, Geranium sanguineum $(38,+)$, Heracleum sphondylium $(19,+; 20, r)$, Hieracium racemosum $(39,1), H$. sp. $(1,1 ; 21, r)$, Hordelymus europaeus $(19$, r; 20 , r), Hypericum hirsutum (30, r; 31, r), Jovibarba hirta $(18,+)$, Juglans regia $(41, \mathrm{r})$, Juniperus communis $(12, \mathrm{r})$, Lamium maculatum $(30,+; 31, r)$, Larix decidua $(17, r)$, Laserpitium latifolium $(19, \mathrm{r} ; 35,+)$, Lilium martagon $(19, \mathrm{r})$, Luzula campestris $(7,+; 13,+)$, Pimpinella saxifraga $(1, \mathrm{r})$, Pinus sylvestris $(13,+; 17, \mathrm{r})$, Platanthera bifolia $(20, \mathrm{r} ; 29$, r), Prunus spinosa $(20, \mathrm{r} ; 24,+)$, Ranunculus auricomus agg. $(20,+)$, Rhamnus catharticus $(31, \mathrm{r})$, Acetosella vulgaris $(18,+)$, Sanicula europaea $(19,+; 24, \mathrm{r})$, Scrophularia nodosa (19, r; 22, r), Senecio ovatus $(19,+; 25, r)$, S. germanicus $(19, \mathrm{r})$, S. sp. $(18, \mathrm{r})$, Sorbus aria $(18,+)$, Stachys alpina (23, r), Urtica dioica $(36, \mathrm{r})$, Verbascum nigrum $(34,+)$, Verbena officinalis $(18,+)$, Vicia cassubica $(40,1)$, V. sepium $(19,+)$, Vincetoxicum hirundinaria $(11, \mathrm{r} ; 27,+)$, Viola mirabilis $(19, \mathrm{r})$, Waldsteinia geoides $(32,+)$.

$\mathbf{E}_{0}$ - moss layer: Brachythecium albicans $(13, \mathrm{r})$, Bryum caespiticium (31, r), Dicranella heteromalla (1, r; 7, r), Dicranum montanum $(9, \mathrm{r})$, Eurhynchium hians (24, r), Homalothecium sericeum $(39,1)$, Hylocomium splendens $(1,1)$, Isothecium myurum $(1,1 ; 30, \mathrm{r})$, Leucodon sciuroides $(5,+; 6, \mathrm{r})$, Mnium stellare $(1,1 ; 3,1)$, Myurella julacea $(28, \mathrm{r})$, Plagiothecium denticulatum (12, r), Pleurozium schreberi $(1,1)$, Pohlia nutans $(13,+)$, Polytrichum juniperinum $(1, a)$, Rhytidiadelphus triquetrus $(1,+)$, Tortula ruralis $(5, r)$, T. subulata $(28, \mathrm{r})$.

\section{Locations of relevés}

Relevé number, locality-village, altitude $(\mathrm{m})$, aspect (in letters), slope (degrees), relevé area, cover of tree layer ( $\left.\mathrm{E}_{3}\right)$, cover of shrub layer $\left(\mathrm{E}_{2}\right)$, cover of herb layer $\left(\mathrm{E}_{1}\right)$, cover of mosses and lichens $\left(\mathrm{E}_{0}\right)$, longitude, latitude, date (day/month/year), relevé author.

1. Kozelník (Dolinka), 490 m, NW, 40, $400 \mathrm{~m}^{2}, \mathrm{E}_{3} 70 \%, \mathrm{E}_{2} 10 \%, \mathrm{E}_{1} 85 \%, \mathrm{E}_{0} 30 \%, 19^{\circ} 00^{\prime} 07.8^{\prime \prime} \mathrm{E}, 48^{\circ} 30^{\prime} 00.9^{\prime \prime} \mathrm{N}, 9.6 .2010$, M. Slezák.

2. Banská Belá, Jergištôlňa (Široký vrch Mt), 635 m, SW, 30, $400 \mathrm{~m}^{2}, \mathrm{E}_{3} 70 \%, \mathrm{E}_{2} 3 \%, \mathrm{E}_{1} 80 \%, \mathrm{E}_{0} 5 \%, 18^{\circ} 54^{\prime} 31.9^{\prime \prime} \mathrm{E}, 48^{\circ} 28^{\prime} 66.1^{\prime \prime} \mathrm{N}$, 17. 6. 2009, M. Slezák.

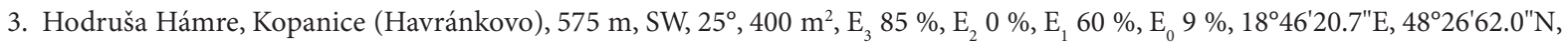
19. 6. 2008, M. Slezák.

4. Bzenica, Chobien Mt., 330 m, SSW, 25, $400 \mathrm{~m}^{2}, \mathrm{E}_{3} 65 \%, \mathrm{E}_{2} 3 \%, \mathrm{E}_{1} 55 \%$, $\mathrm{E}_{0} 10 \%, 18^{\circ} 45^{\prime} 09.6^{\prime \prime} \mathrm{E}, 48^{\circ} 31^{\prime} 62.7^{\prime \prime} \mathrm{N}, 29.6 .2009$, M. Slezák.

5. Bzenica, Hlinická hora Mt., 365 m, S, 15, $400 \mathrm{~m}^{2}, \mathrm{E}_{3} 65 \%, \mathrm{E}_{2} 2 \%, \mathrm{E}_{1} 70 \%, \mathrm{E}_{0} 9 \%, 18^{\circ} 46^{\prime} 03.6^{\prime \prime} \mathrm{E}, 48^{\circ} 31^{\prime} 32.8^{\prime \prime} \mathrm{N}, 29.6 .2009$, M. Slezák.

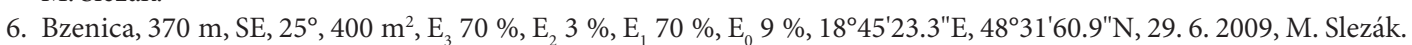

7. Lehôtka pod Brehmi, Gráfovská Mt, 545 m, S, $20^{\circ}, 400$ m², $\mathrm{E}_{3} 65 \%$, E 5 \%, E 70 \%, E 6 \%, 1850'71.6"E, 48³2'79.9"N, 14. 7. 2009, M. Slezák.

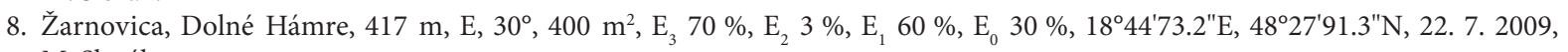
M. Slezák.

9. Žarnovica, Lukavica (Mäsiarka Mt), $531 \mathrm{~m}, \mathrm{SSW}, 25^{\circ}, 400 \mathrm{~m}^{2}, \mathrm{E}_{3} 70 \%, \mathrm{E}_{2} 2 \%, \mathrm{E}_{1} 70 \%, \mathrm{E}_{0} 6 \%, 18^{\circ} 45^{\prime} 27.6^{\prime \prime} \mathrm{E}, 48^{\circ} 29^{\prime} 48.3^{\prime \prime} \mathrm{N}, 27.7$. 2009, M. Slezák.

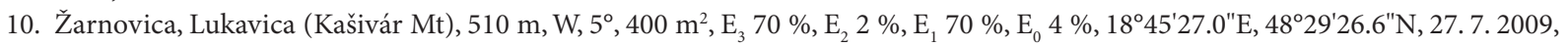
M. Slezák.

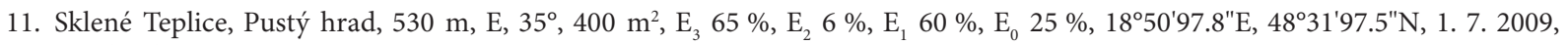
M. Slezák.

12. Žarnovica, Lukavica (Bartkovci), $504 \mathrm{~m}, \mathrm{~W}, 20^{\circ}, 400 \mathrm{~m}^{2}, \mathrm{E}_{3} 70 \%, \mathrm{E}_{2} 2 \%, \mathrm{E}_{1} 70 \%, \mathrm{E}_{0} 15 \%, 18^{\circ} 46^{\prime} 49.2^{\prime \prime} \mathrm{E}, 48^{\circ} 28^{\prime} 70.3^{\prime \prime} \mathrm{N}, 3.8 .2009$, M. Slezák.

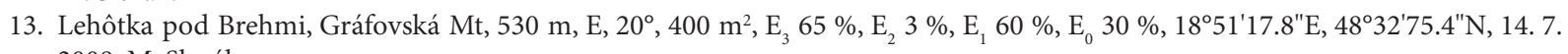
2009, M. Slezák. 


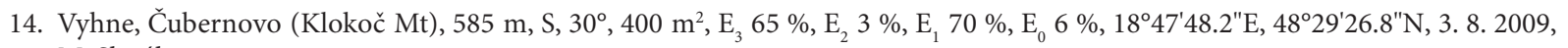
M. Slezák.

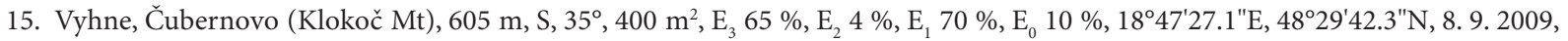
M. Slezák.

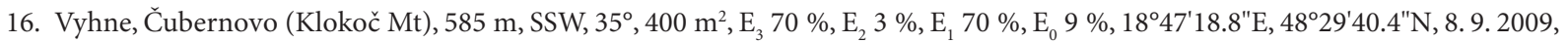
M. Slezák.

17. Vyhne (Šprochová), 515 m, SSW, 30, 400 m², E 60 \%, E 5 \%, E, 60 \%, E 4 \%, 1849'53.6"E, 48²9'85.7"N, 10. 6. 2008, M. Slezák.

18. Vyhne, Spálený vrch Mt, 670 m, SW, 40, 400 m², $\mathrm{E}_{3} 60 \%$, E 5 \%, E 30 \%, E $30 \%, 18^{\circ} 49^{\prime} 13.7^{\prime \prime} \mathrm{E}, 48^{\circ} 29^{\prime} 58.8^{\prime \prime} \mathrm{N}, 10.6 .2008$, M. Slezák.

19. Dobrá Niva, $805 \mathrm{~m}, \mathrm{SW}, 20^{\circ}, 400 \mathrm{~m}^{2}, \mathrm{E}_{3} 80 \%, \mathrm{E}_{2} 10 \%, \mathrm{E}_{1} 80 \%, \mathrm{E}_{0} 0 \%, 19^{\circ} 00^{\prime} 52.2^{\prime \prime} \mathrm{E}, 48^{\circ} 28^{\prime} 69.4^{\prime \prime} \mathrm{N}, 9.6 .2008$, M. Slezák.

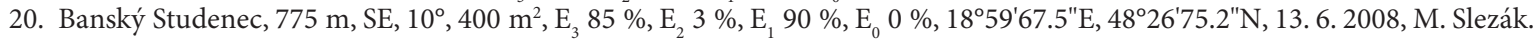

21. Voznica, $420 \mathrm{~m}, \mathrm{SW}, 20^{\circ}, 400 \mathrm{~m}^{2}, \mathrm{E}_{3} 80 \%, \mathrm{E}_{2} 0 \%, \mathrm{E}_{1} 75 \%, \mathrm{E}_{0} 0 \%, 18^{\circ} 43^{\prime} 49.0^{\prime \prime} \mathrm{E}, 48^{\circ} 27^{\prime} 36.3^{\prime \prime} \mathrm{N}, 16.6 .2008$, M. Slezák.

22. Voznica, $425 \mathrm{~m}, \mathrm{SW}, 20^{\circ}, 400 \mathrm{~m}^{2}, \mathrm{E}_{3} 80 \%, \mathrm{E}_{2} 0 \%$, E $80 \%, \mathrm{E}_{0} 0 \%, 18^{\circ} 43^{\prime} 55.0^{\prime \prime} \mathrm{E}, 48^{\circ} 27^{\prime} 28.6^{\prime \prime} \mathrm{N}, 16.6 .2008$, M. Slezák.

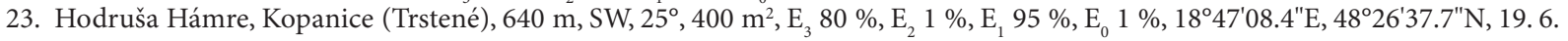
2008, M. Slezák.

24. Šášovské Podhradie (Sut'), 600 m, W, 20 $400 \mathrm{~m}^{2}, \mathrm{E}_{3} 80 \%, \mathrm{E}_{2} 5 \%, \mathrm{E}_{1} 90 \%, \mathrm{E}_{0} 4 \%, 18^{\circ} 55^{\prime} 78.9^{\prime \prime} \mathrm{E}, 48^{\circ} 33^{\prime} 97.4^{\prime \prime} \mathrm{N}, 25.6 .2008$, M. Slezák.

25. Močiar, 670 m, SW, $15^{\circ}, 400 \mathrm{~m}^{2}, \mathrm{E}_{3} 90 \%, \mathrm{E}_{2} 5 \%, \mathrm{E}_{1} 80 \%, \mathrm{E}_{0} 0 \%, 18^{\circ} 57^{\prime} 30.5 " \mathrm{E}, 48^{\circ} 31^{\prime} 25.7^{\prime \prime} \mathrm{N}$, 29. 7. 2008, M. Slezák.

26. Voznica (Ferencky), $380 \mathrm{~m}, \mathrm{SW}, 25^{\circ}, 400 \mathrm{~m}^{2}, \mathrm{E}_{3} 70 \%, \mathrm{E}_{2} 2 \%, \mathrm{E}_{1} 70 \%$, E 0 \% , 18 $8^{\circ} 43^{\prime} 20.8^{\prime \prime} \mathrm{E}, 48^{\circ} 27^{\prime} 39.0^{\prime \prime} \mathrm{N}, 16.6 .2008$, M. Slezák.

27. Hronská Breznica, $635 \mathrm{~m}, \mathrm{~W}, 15^{\circ}, 400 \mathrm{~m}^{2}, \mathrm{E}_{3} 70 \%$, $\mathrm{E}_{2} 5 \%, \mathrm{E}_{1} 90 \%, \mathrm{E}_{0} 0 \%, 19^{\circ} 00^{\prime} 84.0^{\prime \prime} \mathrm{E}, 48^{\circ} 32^{\prime} 54.6^{\prime \prime} \mathrm{N}, 13.7 .2009$, M. Slezák.

28. Banská Belá, Antošíkovci, 625 m, SE, $20^{\circ}, 400 \mathrm{~m}^{2}, \mathrm{E}_{3} 90 \%, \mathrm{E}_{2} 3 \%, \mathrm{E}_{1} 80 \%, \mathrm{E}_{0} 5 \%, 18^{\circ} 57^{\prime} 18.3^{\prime \prime} \mathrm{E}, 48^{\circ} 28^{\prime} 44.7^{\prime \prime} \mathrm{N}, 10.7 .2008$, M. Slezák.

29. Banská Belá, Antošíkovci, 610 m, SE, $20^{\circ}, 400 \mathrm{~m}^{2}, \mathrm{E}_{3} 85 \%, \mathrm{E}_{2} 5 \%, \mathrm{E}_{1} 85 \%, \mathrm{E}_{0} 3 \%, 18^{\circ} 57^{\prime} 20.5^{\prime \prime} \mathrm{E}, 48^{\circ} 28^{\prime} 45.1^{\prime \prime} \mathrm{N}, 10.7 .2008$, M. Slezák.

30. Banská Belá, Antošíkovci, 650 m, NW, 15², 400 m², $\mathrm{E}_{3} 70 \%, \mathrm{E}_{2} 8 \%$, E $80 \%$, $\mathrm{E}_{0} 1 \%$, 1857'31.6"E, 48²8'56.5"N, 10. 7. 2008, M. Slezák.

31. Banská Belá, Antošíkovci, 645 m, SE, 20, 400 m², $\mathrm{E}_{3} 80 \%$, E $3 \%$, E $60 \%$, E 1 \%, 1857'34.5"E, 48²8'57.4"N, 10. 7. 2008, M. Slezák.

32. Močiar, $685 \mathrm{~m}, \mathrm{SSE}, 20^{\circ}, 400 \mathrm{~m}^{2}, \mathrm{E}_{3} 80 \%$, E $3 \%$, E $80 \%, \mathrm{E}_{0} 0 \%, 18^{\circ} 57^{\prime} 45.0^{\prime \prime} \mathrm{E}, 48^{\circ} 31^{\prime} 30.1^{\prime \prime} \mathrm{N}, 29.7 .2008$, M. Slezák.

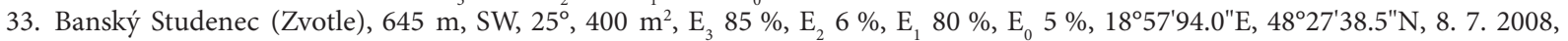
M. Slezák.

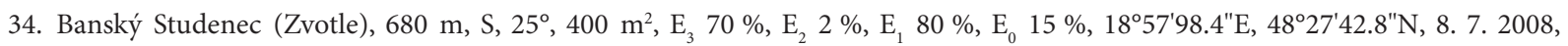
M. Slezák.

35. Banská Belá, Háj, 555 m, W, 25, 400 m² , E 75 \%, E 9 \%, E 60 \%, E 2 \%, 1855'62.5"E, 48²9'23.4"N, 17. 6. 2009, M. Slezák.

36. Sklené Teplice, Drieňový vrch Mt, $694 \mathrm{~m}, \mathrm{~W}, 25^{\circ}, 400 \mathrm{~m}^{2}, \mathrm{E}_{3} 65 \%, \mathrm{E}_{2} 4 \%, \mathrm{E}_{1} 90 \%, \mathrm{E}_{0} 10 \%, 18^{\circ} 53^{\prime} 01.5^{\prime \prime} \mathrm{E}, 48^{\circ} 32^{\prime} 58.6^{\prime \prime} \mathrm{N}, 29.7$. 2009, M. Slezák.

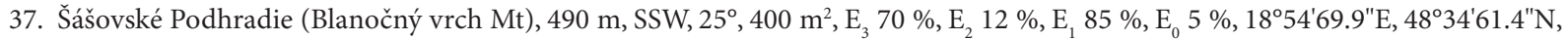
25. 6. 2008, M. Slezák.

38. Šášovské Podhradie (Blanočný vrch Mt), $540 \mathrm{~m}, \mathrm{SW}, 20^{\circ}, 400 \mathrm{~m}^{2}, \mathrm{E}_{3} 50 \%, \mathrm{E}_{2} 12 \%, \mathrm{E}_{1} 80 \%, \mathrm{E}_{0} 4 \%, 18^{\circ} 54^{\prime} 90.9^{\prime \prime} \mathrm{E}, 48^{\circ} 34^{\prime} 63.3^{\prime \prime} \mathrm{N}$, 25. 6. 2008, M. Slezák.

39. Šášovské Podhradie, Istebné valley, 478 m, SE, $30^{\circ}, 400$ m², $\mathrm{E}_{3} 70 \%, \mathrm{E}_{2} 9 \%, \mathrm{E}_{1} 50 \%, \mathrm{E}_{0} 15 \%, 18^{\circ} 53^{\prime} 87.3^{\prime \prime} \mathrm{E}, 48^{\circ} 33^{\prime} 66.7^{\prime \prime} \mathrm{N}, 7.8 .2009$, M. Slezák.

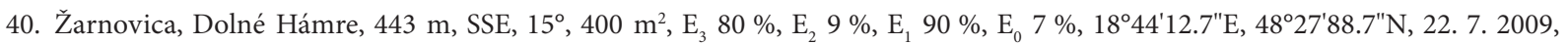
M. Slezák.

41. Žarnovica, Dolné Hámre, 390 m, SW, 20², 400 m², $\mathrm{E}_{3} 80 \%, \mathrm{E}_{2} 6 \%$, E 180 \%, $\mathrm{E}_{0} 6 \%$, 1844'66.1"E, 48²7'89.7"N, 22. 7. 2009, M. Slezák. 